\title{
Cemetery as an Opportunity for Learning outside the Classroom
}

\author{
Polona Jančič Hegediš, Vlasta Hus \\ Faculty of Education, University of Maribor, Maribor, Slovenia \\ Email: polona.jancic1@um.si,vlasta.hus@um.si
}

How to cite this paper: Hegediš, P. J., \& Hus, V. (2020). Cemetery as an Opportunity for Learning outside the Classroom. Creative Education, 11, 2660-2671. https://doi.org/10.4236/ce.2020.1112197

Received: November 13, 2020

Accepted: December 14, 2020

Published: December 17, 2020

Copyright () 2020 by author(s) and Scientific Research Publishing Inc. This work is licensed under the Creative Commons Attribution International License (CC BY 4.0).

http://creativecommons.org/licenses/by/4.0/

\begin{abstract}
In this paper, we present an empirical study with the research purpose to determine the opinions of future teachers on experiential learning outside the classroom in the cemetery. We define experiential learning as learning that combines a person's sensory and emotional experience, thinking, analysis and action into a whole. When planning learning activities of experiential learning outside the classroom, it is necessary to focus on a place that can contribute significantly to a richer learning experience. One of the possible places could be a cemetery. The research sample included 65 students from the last academic year studying primary education at the Faculty of Education of the University of Maribor in Slovenia. The research was conducted in March 2020. The results showed that students associate the word "cemetery" with death, candle, grave and funeral. However, the phrase "teaching at the cemetery" is considered innovative and inappropriate. Most students have no personal experience of teaching in cemeteries. The answers to the question about the appropriateness of teaching at the cemetery are equally divided. Social studies are considered the most appropriate subject for teaching at the cemetery, and sports is the least appropriate. The students also feel that they are not qualified enough to teach outside the classroom.
\end{abstract}

\section{Keywords}

Primary School, Teaching, Learning, Environment, Cemetery, Future Teachers

\section{Introduction}

Current trends in teaching, which promote an active role of students in the learning approach, require highly qualified teachers. It is therefore necessary to train future teachers adequately at all levels of education. Highly qualified teachers will be able to choose and select appropriate teaching forms, methods and 
strategies. They will also be able to plan and implement experiential learning outside the classroom in a diverse environment. In our paper, we focus on students in the 4th year of their faculty studies. These are the students who will later teach the youngest primary school pupils from the 1st to the 5th year of their primary studies.

In the theoretical part of the paper, we first introduce experiential learning, with the emphasis on teaching outside the classroom. We will focus on the cemetery as a place where students can learn about the social, cultural and natural environment. In the empirical part of this paper, we present a study carried out in March 2020, in which all students of their last year, 4th year, of primary education at the Faculty of Education of the University of Maribor participated.

In the past, children learned and prepared themselves for life by watching and imitating the adults in their daily tasks. However, as the school system became increasingly organised and institutionalised, teaching and education became more and more distant from life and work. At school, the emphasis was on rules and laws that were not always related to the pupils' own experiences. It was precisely this distance from real life that made it necessary to update the principle of the vitality of teaching. This is best expressed in experiential teaching and learning (Blažič, Ivanuš Grmek, Kramar, \& Strmčnik, 2003).

\subsection{Experiential Learning outside the Classroom}

Experiential learning can be defined as learning that seeks to connect a person's sensory and emotional experience, thinking, analysing, and acting into a whole. A comprehensive personal experience plays a central role in experiential learning. The result of experiential learning is the knowledge that an individual acquires with his or her involvement (Wurdinger \& Carlson, 2010). We can talk about experiential learning in any learning where the student is in direct contact with the reality he is studying, which is the complete opposite of traditional passive learning. At the same time, we must pay attention to the fact that not every learning based on life experiences is necessarily reliable knowledge (Marentič Požarnik et al., 2019).

Experiential learning can also be done outside the classroom, on-site. When planning learning activities, it is necessary to focus on a location that can contribute significantly to a richer learning experience. When planning the learning process itself, not only what we learn is essential, but also how and where we learn. It is necessary to ask ourselves what we want to achieve, how we will achieve it, where we can create these conditions and why this is so. The experiences we have outside the classroom are more authentic and better understood than those we have in the classroom (Waite, 2017). Outdoor learning is defined as what happens outside the walls of closed rooms. It should provide students with more memorable and exciting learning experiences and encourage excitement, interest and motivation to learn. It is often used for objects or topics that require specific illustrations to help to understand. In general, outdoor learning offers opportunities for use in many subjects because it supports the holistic development of 
children (Harris, 2017). Fieldwork defines the learning skills and activities of all students outside the classroom, so that the implementation of outdoor learning varies significantly in time, from a few minutes to a few days (Kolenc Kolnik, 2007). From the point of view of the sustainability of knowledge, fieldwork is more efficient than other forms of work, simply because fieldwork involves more sensorimotor functions than, for example, simple listening (Črešnar 2011). Cornell (1994) wrote that direct personal experience facilitates memory, which is more deeply rooted in memory. Nature requires us to use all the senses, i.e. feeling, smelling, tasting, seeing and hearing.

Although teaching outside the classroom looks more playful and less binding, it is a form of deliberately focused and organised student-centred education (Waite, 2019). The organisation of outdoor lessons requires a lot of knowledge and experience, preparation, and safety measures from the teacher. According to Borsos et al. (2018), the prerequisite for successful outdoor learning is that the teacher is aware of the reason for conducting outdoor lessons, that he or she knows the place well and has prepared appropriate tasks to guide the learning process. In this way, the teacher can successfully realise active learning, because otherwise outdoor teaching will be similar to classroom teaching and the teacher will not be able to take advantage of the motivating opportunities offered by outdoor space.

\subsection{The Educational Potential of Cemetery}

The choice of the place where the lessons take place outside the classroom plays an essential role in the learning process. Pliberšek and Vrban (2019) wrote that a cemetery could be used as an outdoor classroom. The cemetery can provide the students with a powerful and unforgettable learning experience. The cemeteries themselves tell the history of the towns and their inhabitants, the changing customs of different social classes and the fashion that can be deduced from the memorial documents on the gravestones. The cemetery can be accepted as an open-air museum, where you can learn a lot about the culture and history of the place where the cemetery is located. We can find out which celebrities once lived at this place and what their function and contribution to this place was. We associate them with the culture of the people and their customs, symbols and the development of the place (Kear, 2009).

A visit to the cemetery offers teachers the opportunity to include primary historical sources in their lessons, through which they learn about the history of their own place.

\section{Methodology}

\subsection{Purpose of the Study}

The main research purpose in our study was to determine the opinions of future teachers on experiential learning outside the classroom in the cemetery.

In our research we were interested in: 
- What are the most common student associations with the word "cemetery" and "teaching at cemeteries"?

- How many times a year do students visit the cemetery?

- Have students ever visited a cemetery during their elementary education?

- Do students find the cemetery as a suitable place for primary school lessons, and which subjects of primary school could be taught at cemeteries?

- Would students conduct teaching at the cemetery?

- Do the students feel qualified enough to teach in the cemetery?

\subsection{The Basic Research Study}

The study was based on a descriptive and non-experimental method of empirical research. Since we did not implement any form of pedagogical experiment during this research the most appropriate research method was descriptive statistical method of empirical research. It is typical for the descriptive research method of empirical pedagogical research to teach by describing facts, relationships, and processes without sample explanation.

\subsection{Sample}

The number of students, the future primary school teachers, who participated in the convenience sample, was 65 . Students were in their 4 th year of Primary education studies at the Faculty of Education at University of Maribor. This is their last academic year for the first Bologna cycle. The research sample included all 4th year. These students, were selected because at the end of their studies they had already participated in lessons on experiential learning and outdoor education.

\subsection{Data Collection}

After an extensive review of the literature and curricula for primary education, we designed a questionnaire. The data for all variables were collected with this questionnaire. We printed out the questionnaire and the 4th year primary education students completed it anonymously. The questionnaire consisted of various types of questions-dichotomous questions, close-ended, open-ended, Likert scale. The data were collected in March 2020.

\subsection{Data Analysis}

The data obtained from the questionnaire were analysed using the SPSS statistics programme. Data was processed using basic descriptive statistics, frequency distribution.

\section{Results}

\subsection{Student Associations to the Cemetery and Classes at the Cemetery}

At the beginning of the questionnaire students had to write their first three associations for the word "cemetery". When analysing the data, we found that the 
students wrote 27 different associations. In the figure below we present the 10 most frequently written individual associations. Other associations were recorded only twice or once.

As shown in Figure 1, the death was written by up to 32 students and the candle by 31 students. The grave was held by 21 students. It was followed by funeral (15 students), flowers (13 students), sadness (11 students), tombstone (10 students), deceased (7 students), family (6 students) and church (3 students).

In addition, the students had to write down 3 of their first associations for the phrase teaching in the cemetery. We have listed 71 different associations for this phrase. Figure 2 shows the 10 associations most frequently chosen by the students.

Figure 2 shows that there were not so many similar associations compared to the word cemetery. The associations that most students (7) wrote on the word phrase teaching in the cemetery are innovative and etiquette. What follows is an inappropriate written by six students. Five students wrote down the following associations: learning, sadness, interesting, death, tombstone and November 1st. The silence was an association chosen by four students. All other 61 of total 71 associations were chosen by three or less students.

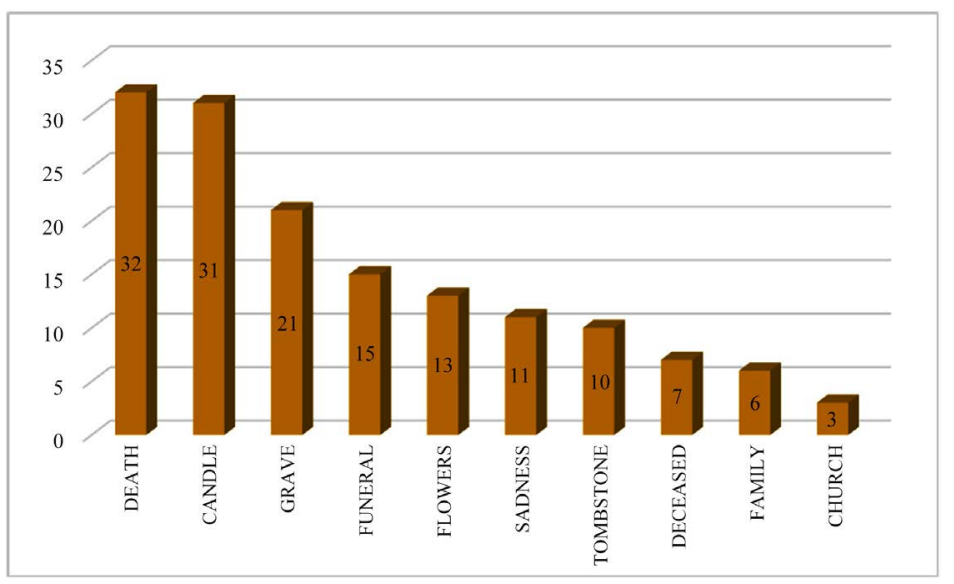

Figure 1. Number (f) od respondents associations for the word "cemetery".

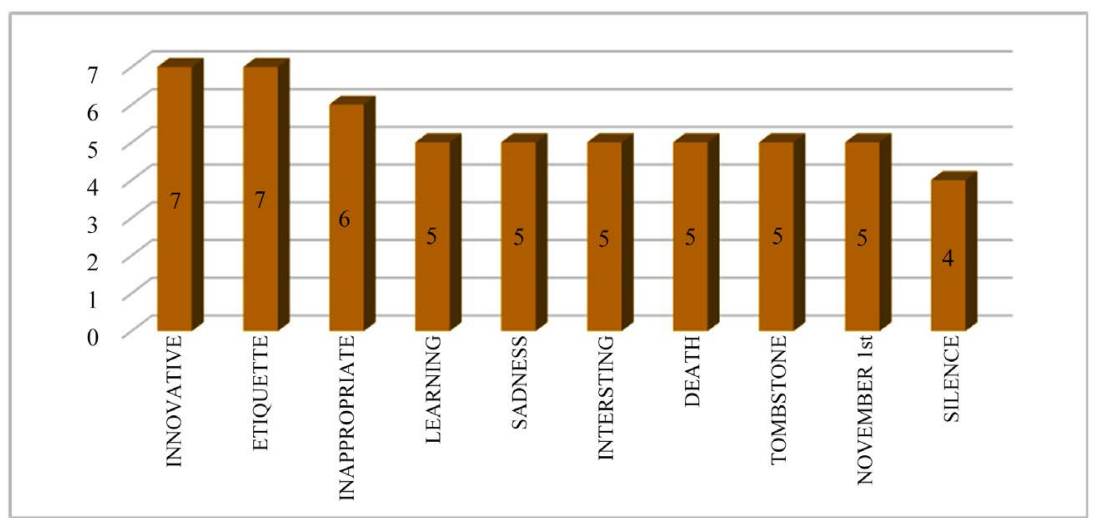

Figure 2. Number (f) od respondents associations for the phrase "teaching in the cemetery". 


\subsection{Visits of the Cemetery}

\section{How many times a year do students visit a cemetery?}

The results showed that students visit the cemetery on average 14.03 times a year, which means about once a month.

Table 1 shows that the maximum value we received was 104 times per year, which means that at least one of the participating students goes to the cemetery twice a week. However, at least one participating student stated that he never goes to the cemetery.

Have students ever visited a cemetery during their elementary education?

We were interested to know whether the participating students had any personal experience with teaching at the cemetery. Therefore we asked students if they had ever visited the cemetery as elementary school students during their lessons in an organised way. Figure 3 shows that only $27.7 \%$ of them visited the cemetery during their primary school years. So most of the students we asked (72.30\%) have no experience of teaching at the cemetery.

Those who had an experience of teaching at the cemetery during their primary school years were also asked what memories they had of this teaching. Ten students have a positive memory of such a lesson. Seven students do not remember and cannot decide whether it was a positive or negative experience. However, only one student has a negative memory of such a lesson. The other students did not answer this question.

\subsection{Carrying out the Lessons in the Cemetery}

Do students find the cemetery a suitable place for primary school lessons?

In the next question, we were interested if the students find the cemetery a suitable place for primary school lessons.

As can be seen in Figure 4, students' responses are divided equally. Thirtythree students, or $50.8 \%$ of the participating students, answered that they consider the cemetery to be a suitable place for teaching. Thirty-two students, or $49.2 \%$ of the participating students, answered that the cemetery is not a suitable place for teaching.

In which school subjects do the students think that the cemetery could be used for teaching?

When asked this question, the students indicated, in the case of an individual subject taught at the elementary level, whether or not they could teach that subject at the cemetery.

Figure 5 shows that the majority of students, 64 , i.e. $98.5 \%$ of all respondents, stated that lessons at the cemetery could be conducted in the subject Social Studies. The majority of students believe that the lessons at the cemetery could also be conducted in the subjects Environmental Studies (55 pupils, 84.6\%), art and language (49 students). Only a few students would teach sport at the cemetery (6 pupils, 9.2\%). However, students were most indecisive in the natural sciences: up to 20 , or $30.8 \%$ of all participants, stated that they could not define themselves. 
Table 1. Number of respondents' cemetery visits per year.

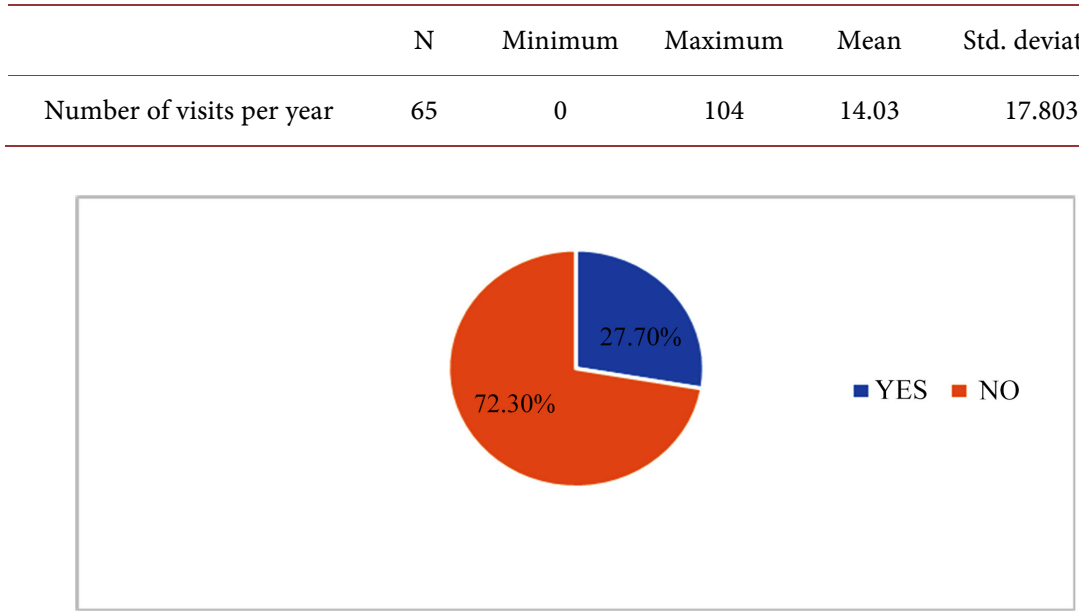

Figure 3. Structural percentage (f\%) of respondents' experiences of visiting cemeteries in their primary school.

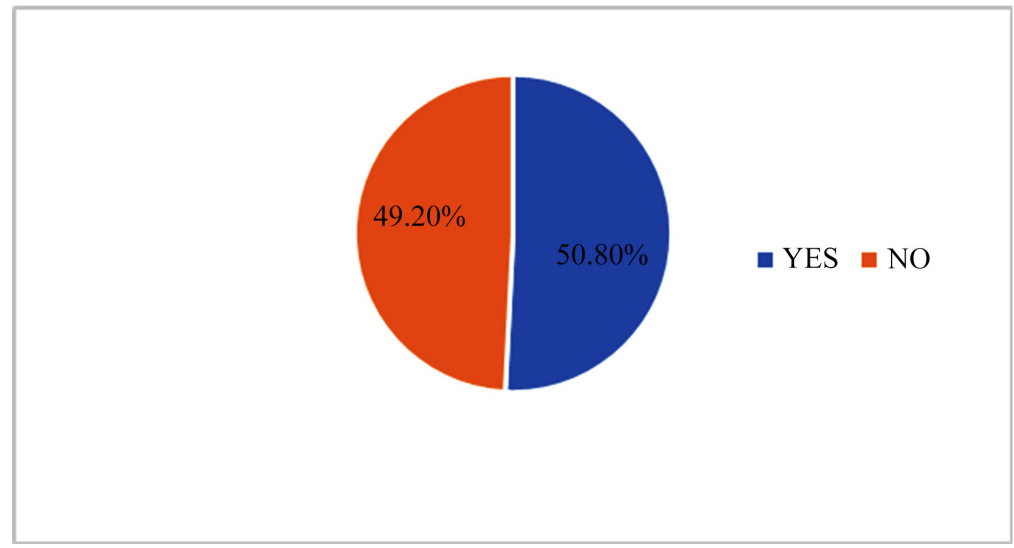

Figure 4. Structural percentage (f\%) of respondents' answers on whether they consider cemetery to be a suitable place for teaching.

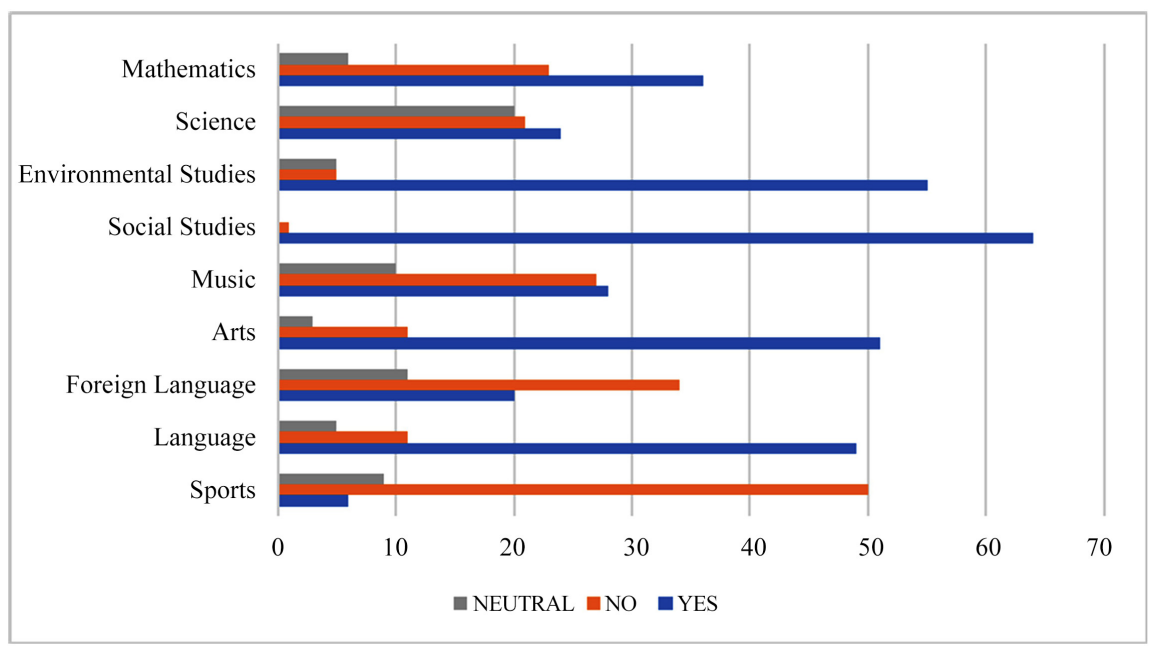

Figure 5. Graph of the structural percentages (f\%) of respondents' opinions of learning possibilities in cemetery by each subject. 


\section{Would students conduct classes in the cemetery?}

In addition, students indicated on a scale of 1 to 5 whether they would be teachers who would perform some lessons at the cemetery. Where 1 meant no, definitely not and 5 meant definitely yes-I would teach at a cemetery. The data are shown in Table 2.

Table 2 shows that the majority of students $(38.5 \%)$ on the scale indicated that they would probably not teach in a cemetery. $30.8 \%$ of the students surveyed stated that they did not know and could not decide whether they would teach at a cemetery. $21.5 \%$ of the students would most likely teach at a cemetery and $6.2 \%$ of the students interviewed would teach at a cemetery. However, two of the surveyed students (3.1\%) would certainly not teach at a cemetery.

\subsection{Qualification of the Students}

At the end of the questionnaire, students evaluated on a 5-point scale, whether they think they are sufficiently qualified to teach in the cemetery.

Table 3 shows that the majority of students (32.3\%) think that they are not sufficiently qualified to teach at the cemetery. $30.8 \%$ of the participating students could not identify themselves, so they feel neither qualified nor incompetent. $21.5 \%$ of the students believe that they are partially qualified and $6.2 \%$ of the students believe that they are qualified to teach at the cemetery. At the end of their undergraduate studies, $9.2 \%$ of the participating students believe that they are not at all qualified for teaching at the cemetery.

Table 2. Students answers on whether they would perform teaching in the cemetery.

\begin{tabular}{ccc}
\hline Answers & $\mathrm{f}$ & $\mathrm{f} \%$ \\
\hline 1 (No, definitely not) & 2 & $3.1 \%$ \\
2 (Probably not) & 25 & $38.5 \%$ \\
3 (Neutral) & 20 & $30.8 \%$ \\
4 (Maybe yes) & 14 & $21.5 \%$ \\
5 (Definitely yes) & 4 & $6.2 \%$ \\
Total & 65 & $100.0 \%$ \\
\hline
\end{tabular}

Table 3. Students answers on whether they think they are qualified to teach in the cemetery.

\begin{tabular}{ccc}
\hline Answers & $\mathrm{f}$ & $\mathrm{f} \%$ \\
\hline 1 Not qualified at all & 6 & $9.2 \%$ \\
2 Not sufficiently qualified & 21 & $32.3 \%$ \\
3 Neither unqualified, neither qualified & 20 & $30.8 \%$ \\
4 Partially qualified & 14 & $21.5 \%$ \\
5 Qualified & 4 & $6.2 \%$ \\
Total & 65 & $100.0 \%$ \\
\hline
\end{tabular}




\section{Discussion}

The present study aimed to investigate the attitude of students of primary education in their last year of undergraduate studies towards the cemetery and teaching outside the classroom in the cemetery. During the research, we asked them about their associations with the word cemetery and results show that the words death, candle and grave occur in most cases. Words that we associate with mourning, sadness and farewell. None of the students' listed anything in connection with our research topic, which leads us to believe that the students do not see the cemetery as a place and opportunity for education. The associations with the phrase learning in the cemetery confirmed our assumption that this topic is not close to students and that it is not something familiar to them. The associations that most students wrote with the phrase cemetery lessons are innovative and etiquette, so we can assume that students believe that learning about the word cemetery would mean for students that the school prepares and teaches etiquette in the cemetery. Nevertheless, the word innovative suggests more advanced thinking, at least for a few students. Another important information is the inappropriate association written by the third-highest number of students. We conclude that there are a few students who find the lessons at the cemetery inappropriate.

Concerning conducting lessons outside the classroom at the cemetery, the results show that half of the participating students consider the cemetery a suitable place for lessons. Choosing from an array of school subjects, almost all students believe that Social Studies lessons could be held at the cemetery. The lowest number of students see the possibility of holding lessons at the cemetery in the subject of sports, which is a reasonable answer to be expected given the appropriate behaviour at the cemetery, which requires peaceful and quiet activities. The content that can be discussed at cemeteries covers several areas and can be well interdisciplinary. Topics of history, geography, culture, visual arts and music are suitable for discussion at the cemetery. Of course, also the contents of Social Studies, where we suggest the treatment of customs and habits, the culture of behaviour at the cemetery and the handling of religious symbols. The pupils can also achieve the goals of mathematics in the cemetery, i.e. they can arrange natural numbers according to size, count, combine different mathematical operations, measure, etc.

A visit to the cemetery offers teachers the opportunity to incorporate primary historical resources into their lessons, through which they learn about the history of their own place. We give an example of gravestones that not only have a function but provide information about dates of birth and death, family names, family relationships and contain various records and expressions that give an insight into life in the past. The motives on the gravestones are a form of popular expression in the past and have a deeper symbolic function. A cemetery is a place that is usually easily accessible as it is located in almost any place or community, and entry is free and does not require any particular funding. 
Despite the fact that teaching outside the classroom is often mentioned as a positive phenomenon, there are still too few teachers and schools that provide only classroom teaching. Due to the demand for academic knowledge and skills, teachers often focus on tests, learning outcomes, curriculum goals and effective methods of achieving these goals, which they pursue in the classroom, as they perceive outdoor teaching as a more time-consuming method (Skaugen \& Fiskum, 2015).

The results show that most of the students would not conduct any lessons outside the classroom in a cemetery. No less than a third of the pupils are still undecided about conducting lessons at the cemetery. From the results of the question, which show that students do not feel qualified to teach at the cemetery, we can conclude that insufficient qualification is possibly one of the reasons why they would not choose to teach at the cemetery. It is also a disadvantage that most of the students have no personal experience of teaching at the cemetery from their primary school days.

Indeed, teaching outdoors is physically and mentally demanding. It is crucial to ensure that the teacher's efforts are not in vain, as there are good reasons to teach outdoors (Bilton, 2010). As an example of good practice in cemeteries, in Slovenia, there is the Pobrežje cemetery, which is managed by Pogrebno podjetje Maribor d.d. There it is possible to explore the cemetery with the help of mobile learning platforms ARtour (ASCE, b.d.). The application guides the user through significant graves and exciting places in the cemetery. The user of ARTour has three thematic paths available in Slovenian and English language, through which teachers and pupils can also explore professional symbols, religious symbols and symbols of destiny. Pogrebno podjetje Maribor d.d. offers schools a variety of educational programs for educational purposes. One of the programs is a cultural day, where students learn about history and art in stories through symbols, celebrities and events.

It depends on the qualifications and expertise whether the teachers will even recognise the possibilities of teaching at the cemetery and consequently decide to do so. The results of the research showed that $32.8 \%$ of the students believe that they are not sufficiently qualified, and 9.2\% that they are not qualified at all for teaching at the cemetery. It is also important to note that $30.8 \%$ of the students could not decide whether they are sufficiently qualified or not. As these are students in their final year of study, it can be summarised that there is a tendency that students do not acquire sufficient knowledge for teaching at the cemetery during their studies. Here is the lack in our research, that we did not include an additional question in the questionnaire and investigated whether the students feel qualified to teach outside the classroom in a different environment. The question arises whether the cemetery as the chosen location for teaching outside the classroom is the element through which the students feel insufficiently educated and whether their answers would be different if they were asked, for example, about teaching outside the classroom in the forest. The fact is, that the contents 
of learning outside the classroom are included in several subjects of the primary education of the Faculty of Education in Maribor. Nowhere is the cemetery explicitly mentioned as a possible place for lessons.

As one of the possibilities of training students for teaching outside the classroom, the Faculty of Education in Maribor offers students the elective subject Activities outside the classroom in the Environmental and Social Studies. This subject aims to familiarise students with the basics of teaching outside the classroom and to train them for transfer into practice. This subject can be taken by the students of the first cycle study program Primary education at the Faculty of Education of the University of Maribor. The content of the subject deals, among other things, with didactic approaches, methods of evaluation, planning, preparation and implementation of the teaching of environmental and social studies outside the classroom. An excursion is also used among the methods and forms of teaching students.

\section{Conclusion}

Based on the findings of this research paper, we expect that the experts will be able to adapt the methods of primary education studies and plan additional training for teachers in service and for future teachers. Based on the findings, an update of the curricula for future primary school teachers can be written. Experiential learning plays an essential role in teacher training. What students learn and apply in different subject areas during their studies, they try to apply later in class. For this reason, Korošec, Ambrožič Dolinšek and Hus (2009) and Črešnar (2011) also find that it makes sense for students to gain as much experience as possible with experiential learning during their studies. Students would acquire in-depth knowledge in a variety of subject areas. Experience with various supportive methods of experiential learning would help to make better use of the knowledge later in class. At the same time, knowledge about experiential learning outside the classroom could mean a more varied combination and implementation of activities later in practice. Our research can be a valuable addition when planning additional and broader research on a very interesting topic of experiential learning, especially experiential learning outside the classroom.

\section{Conflicts of Interest}

The authors declare no conflicts of interest regarding the publication of this paper.

\section{References}

ASCE (b.d). http://www.significantcemeteries.org/p/the-association.html

Bilton, H. (2010). Outdoor Learning in the Early Years. Management and Innovation (3rd ed.). New York: Routledge. https://doi.org/10.4324/9780203860137

Blažič, M., Ivanuš Grmek, M., Kramar, M., \& Strmčnik, F. (2003). Didaktika. [Didactics.] Novo mesto: Visokošolsko središče Novo mesto, Inštitut za raziskovalno in razvojno delo. 
Borsos, E., Patocskaj, M., \& Borić, E. (2018) Teaching in Nature? Naturally! Journal of Biological Education, 52, 429-439.

Cornell, J. (1994). Približajmo naravo otrokom. [Sharing nature with children]. Celje: Mohorjeva družba.

Črešnar, A. (2011). Pomen terenskega dela pri pouku biologije. [The importance of field work in the teaching of biology.] Radovljica: Didakta.

Harris, F. (2017). Outdoor Learning Spaces: The Case of Forest School. Area, 50, 222-231. https://doi.org/10.1111/area.12360

Kear, M. R. (2009). In Reverence: A Plan for the Preservation of Tolomato Cemetery, St. Augustine, Florida. https://ecommons.cornell.edu/handle/1813/13755

Kolenc Kolnik, K. (2007). Proaktivnost in terensko delo v izobraževanju za trajnostni razvoj. Revija za geografijo [Journal for geography], 2, 24-32.

Korošec, U., Ambrožič Dolinšek, J. in Hus, V. (2009). Pomen terenskega dela za bodoče učitelje razrednega pouka. Revija za elementarno izobraževanje [Journal for Elementary Education], Nr. 1, 49-58.

Marentič Požarnik, B., Šarić, M. \& Šteh, B. (2019). Izkustveno učenje. [Experiental learning.] Ljubljana: Znanstvena založba Filozofske fakultete Univerze v Ljubljani.

Pliberšek, L., Vrban, D. (2019). Cemeteries as Cultural Heritage: Implementing the Model of Cemeteries-Cultural Heritage as Education Environment. Journal of Innovative Business and Management, 11, 22-31. https://doi.org/10.32015/JIBM/2019-11-2-3

Skaugen, R., \& Fiskum, T. A. (2015). How Schools with Good Academic Results Justify Their Use of Outdoor Education. International Education Research, 3, 16-31.

Waite, S. (2017). Children Learning Outside the Classroom: From Birth to Eleven. London: SAGE.

Waite, S. (2019). Outdoor Learning Research: Insight into Forms and Functions. Abingdon: Routhledge.

Wurdinger, S. D., Carlson, J. A. (2010). Teaching for Experiential Learning: Five Approaches That Work. Lanham, MD: Rowman and Littlefield Education. 